\title{
The influence of socioeconomic deprivation on multimorbidity at different ages:
}

\author{
a cross-sectional study
}

\begin{abstract}
Background

Multimorbidity occurs at a younger age in individuals in areas of high socioeconomic deprivation but little is known about the 'typology' of multimorbidity in different age groups and its association with socioeconomic status.

\section{Aim}

To characterise multimorbidity type and most common conditions in a large nationally representative primary care dataset in terms of age and deprivation.
\end{abstract}

\section{Design and setting}

Cross-sectional analysis of 1272685 adults in Scotland.

\section{Method}

Multimorbidity type of participants (physicalonly, mental-only, mixed physical, and mental) and most common conditions were analysed according to age and deprivation.

\section{Results}

Multimorbidity increased with age, ranging from $8.1 \%$ in those aged $25-34$ to $76.1 \%$ for those aged $\geq 75$ years. Physical-only $156 \%$ of all multimorbidity) was the most common type of multimorbidity in those aged $\geq 55$ years, and did not vary substantially with deprivation. Mentalonly was uncommon ( $4 \%$ of all multimorbidity), whereas mixed physical and mental $(40 \%$ of all multimorbidityl was the most common type of multimorbidity in those aged $<55$ years and was two- to threefold more common in the most deprived compared with the least deprived in most age groups. Ten conditions (seven physical and three mental) accounted for the top five most common conditions in people with multimorbidity in all age groups. Depression and pain featured in the top five conditions across all age groups. Deprivation was associated with a higher prevalence of depression, drugs misuse, anxiety, dyspepsia pain, coronary heart disease, and diabetes in multimorbid patients at different ages.

\section{Conclusion}

Mixed physical and mental multimorbidity is common across the life-span and is exacerbated by deprivation from early adulthood onwards.

\section{Keywords}

chronic disease; mental health; multimorbidity; primary health care; socioeconomic status.

\section{INTRODUCTION}

Multimorbidity, defined here as the coexistence of two or more chronic conditions in the same individual, presents a challenge to patients, clinicians, healthcare systems, and researchers. ${ }^{1-4}$ Multimorbidity is associated with poor health outcomes, including higher mortality ${ }^{5,6}$ and lower quality of life, ${ }^{7}$ resulting in more complex healthcare needs ${ }^{8}$ and higher healthcare costs. ${ }^{9,10}$ Estimates of the prevalence of multimorbidity vary depending on the study population, the definition of multimorbidity used, and the use of different numbers and definitions of conditions. ${ }^{11,12}$ Regardless of how it is measured, multimorbidity is more common in older people, ${ }^{13,14}$ and in more deprived populations. ${ }^{15}$

To date, research on multimorbidity has mainly focused on older people. ${ }^{16-19}$ However, several studies have shown that multimorbidity is not just a problem of old age. 15,20,21 Indeed, a recent large study found more people with multimorbidity aged $<65$ than $\geq 65$ years. ${ }^{15}$ Higher rates of multimorbidity in younger age groups are particularly common in deprived areas. ${ }^{15,22}$ Studies that have examined multimorbidity across age groups have generally been small, included only a small number of conditions, or have been based on selfreporting. ${ }^{16-18}$

G McLean, $\mathrm{PhD}$, research associate; $\mathbf{S}$ Wyke, $\mathrm{PhD}$, FRCGP (Hon), professor of health and wellbeing; GCM Watt, MD, FRCGP, Norie Miller professor of general practice; D Blane, MBChB, MPH, academic clinical fellow; SW Mercer, PhD, FRCGP, professor of primary care research, Institute of Health and Wellbeing, University of Glasgow, Glasgow, UK. J Gunn, FRACGP, DRANZCOG, PhD, chair of primary care research, head of general practice and primary health care academic centre, Primary Care Research Unit, University of Melbourne, Melbourne, Australia. B Guthrie, MB, $\mathrm{BChir}, \mathrm{PhD}$, professor of primary care medicine, Quality, Safety and Informatics Research Group,
A life-course approach to understanding the aetiology of chronic diseases has been well documented for single physical conditions, ${ }^{23}$ and more recently for single mental conditions such as depression. ${ }^{24} \mathrm{~A}$ recent systematic review, however, found few prospective cohort studies specifically designed to investigate multimorbidity. ${ }^{11}$ Therefore, the aim of this study was to characterise the prevalence and type of multimorbid conditions by socioeconomic status across different age groups, using cross-sectional data from a large, nationally representative primary care dataset, to help inform future prospective studies.

\section{METHOD}

The dataset was obtained from the Primary Care Clinical Informatics Unit at the University of Aberdeen, UK, and included copies of clinical data for 1751841 patients of all ages, permanently registered with 314 Scottish general practices, who were alive on 31 March 2007. ${ }^{15}$ The dataset consisted of complete copies of clinical data for all registered patients caring for about one-third of the Scottish population. Participating practices systematically used electronic medical records for registration of patients, morbidity recording, and prescriptions. The dataset has the same age and sex profile and a similar socioeconomic

University of Dundee, Dundee, UK.

\section{Address for correspondence}

Stewart W Mercer, Institute of Health and Wellbeing, University of Glasgow, 1 Horselethill Road, Glasgow G12 9LX, UK.

E-mail: stewart.merceragla.ac.uk

Submitted: 23 January 2014; Editor's response: 23 February 2014; final acceptance: 8 April 2014 CBritish Journal of General Practice

This is the full-length article (published online 30 Jun 2014) of an abridged version published in print. Cite this article as: Br J Gen Pract 2014; DOI: 10.3399/bjgp14X680545 


\section{How this fits in \\ Multimorbidity is more common and occurs at a younger age in individuals in areas of high socioeconomic deprivation, but the 'typology' of multimorbidity in different age and socioeconomic groups is not well characterised. Multimorbidity of physical conditions only is most common in those aged $\geq 55$ years, and is not substantially related to socioeconomic status, whereas mixed physical and mental multimorbidity is most common in those aged $<55$ years and is two- to threefold more common in the most deprived compared with the least deprived. Ten conditions (seven physical and three mental) accounted for the top five most common conditions in those with multimorbidity in all age groups, with depression and pain featuring in the top five conditions in all age groups. Multimorbidity type thus varies substantially with age and deprivation, and understanding the illness trajectories of people with multimorbidity at different ages is important in the development of future interventions in primary care.}

distribution to the Scottish population overall.25 The NHS National Research Ethics Service have previously approved the use of these anonymised data for research purposes and this analysis did not require independent review. ${ }^{15}$ Socioeconomic status was measured by the postcode-derived Carstairs score lgrouped into tenths of the distribution), which is widely used for research purposes. ${ }^{26,27}$ Individuals were

\section{Table 1. Prevalence of chronic morbidity}

\begin{tabular}{|c|c|c|c|c|}
\hline $\begin{array}{l}\text { Age group, } \\
\text { years }\end{array}$ & $\begin{array}{c}\text { Adult population } \\
(n=1272685) \\
n(\%, 95 \% \mathrm{Cl})\end{array}$ & $\begin{array}{l}\text { No conditions } \\
(n=597363) \\
n(\%, 95 \% \mathrm{Cl})\end{array}$ & $\begin{array}{l}\text { One condition } \\
(n=279015) \\
n(\%, 95 \% \mathrm{Cl})\end{array}$ & $\begin{array}{c}\text { Two or more } \\
\text { conditions } \\
(n=396307) \\
n(\%, 95 \% \mathrm{Cl})\end{array}$ \\
\hline $25-34$ & $\begin{array}{l}229396(18.0) \\
(17.9 \text { to } 18.1)\end{array}$ & $\begin{array}{l}169747(74.0) \\
\text { (73.8 to } 74.0)\end{array}$ & $\begin{array}{l}40962(17.9) \\
(17.7 \text { to } 18.0)\end{array}$ & $\begin{array}{l}18687(8.1) \\
(8.0 \text { to } 8.2)\end{array}$ \\
\hline $35-44$ & $\begin{array}{l}278993 \text { (21.9) } \\
\text { (21.8 to 22.0) }\end{array}$ & $\begin{array}{l}179338 \text { (64.3) } \\
\text { (64.2 to } 64.4)\end{array}$ & $\begin{array}{l}60771(21.8) \\
\text { (21.7 to } 21.9)\end{array}$ & $\begin{array}{l}38884(13.9) \\
\text { (13.8 to } 14.0)\end{array}$ \\
\hline $45-54$ & $\begin{array}{l}253794 \text { (19.9) } \\
\text { (19.8 to 20.0) }\end{array}$ & $\begin{array}{l}131920(52.0) \\
(51.0 \text { to } 52.1)\end{array}$ & $\begin{array}{l}63453(25.0) \\
(24.9 \text { to } 25.1)\end{array}$ & $\begin{array}{l}58421 \text { (23.0) } \\
\text { (22.8 to 23.2) }\end{array}$ \\
\hline 55-64 & $\begin{array}{l}219333(17.2) \\
\text { (17.1 to } 17.3)\end{array}$ & $\begin{array}{l}75843(34.6) \\
\text { (34.5 to } 34.7 \text { ) }\end{array}$ & $\begin{array}{l}58171(26.5) \\
(26.3 \text { to } 26.7)\end{array}$ & $\begin{array}{l}85319 \text { (38.9) } \\
\text { (38.7 to } 39.1 \text { ) }\end{array}$ \\
\hline $65-74$ & $\begin{array}{l}155280(12.2) \\
\text { (12.1 to } 12.3)\end{array}$ & $\begin{array}{l}28662(18.5) \\
\text { (18.3 to } 18.7)\end{array}$ & $\begin{array}{l}35068(22.6) \\
\text { (22.4 to } 22.8)\end{array}$ & $\begin{array}{l}91550 \text { (59.0) } \\
\text { (58.7 to } 59.2 \text { ) }\end{array}$ \\
\hline$\geq 75$ & $\begin{array}{l}135889(10.7) \\
\text { (10.6 to } 10.8)\end{array}$ & $\begin{array}{l}11853 \text { (8.7) } \\
\text { (8.5 to } 8.9 \text { ) }\end{array}$ & $\begin{array}{l}20590(15.2) \\
(15.0 \text { to } 15.3)\end{array}$ & $\begin{array}{l}103446 \text { (76.1) } \\
\text { (75.9 to } 76.3 \text { ) }\end{array}$ \\
\hline
\end{tabular}

Analysis based on 40 chronic conditions: 32 physical and eight mental. Percentages in 'adult population column relate to distribution of age groups within the sample, whereas percentages in the conditions columns relate to distribution within each separate age group. placed in deciles based on the range for the whole of Scotland.

In total, 40 conditions were selected as outlined in detail previously. ${ }^{15}$ Definitions were based on a combination of Quality and Outcomes Framework business rules, ${ }^{28}$ Read Codes, and prescription data.

Multimorbidity was defined as the presence of two or more of these 40 conditions in one patient (32 physical and eight mentall. To characterise the prevalence and type of multimorbidity, patients were grouped as follows:

- two or more physical conditions but no mental health conditions (physical-only);

- two or more mental health conditions but no physical conditions (mental-only); or

- two or more conditions including at least one physical and one mental (mixed physical and mentall.

The top 10 most common conditions in those with multimorbidity were then examined in each age group. Conditions that shared a common vascular aetiology and usually have similar chronic management and treatment goals were classified as concordant (coronary heart disease [CHD], chronic kidney disease [CKD], diabetes, hypertension, heart failure, stroke/TIA, atrial fibrillation and peripheral vascular disease $[P V D])$, with the remainder being classified as discordant. ${ }^{29}$

As the current analysis focused on adults with multimorbidity, patients were divided into six age groups $(25-34,35-44,45-54$, $55-64,65-74$, and $\geq 75$ years) to reflect different stages in the life course. Those $<25$ years were excluded as only $1.9 \%$ have multimorbidity. ${ }^{15}$

Associations between prevalence and socioeconomic deprivation were assessed using Spearman rank correlations. Ten conditions were also compared that featured in the top five ranking conditions across any age groups for the least and most deprived deciles. The $t$-test and one-way ANOVA were used to analyse differences in type of multimorbidity and prevalence of individual conditions between age groups and least and most deprived deciles. All analysis was conducted using Stata (version 11.1).

\section{RESULTS}

\section{Multimorbidity prevalence}

Table 1 shows differences in prevalence of morbidity in adults across the different age groups. The number and percentage of people with multimorbidity were higher in each successive age group, rising from 
Table 2. Type of multimorbidity for people with any multimorbidity

\begin{tabular}{|c|c|c|c|}
\hline Age group & $\begin{array}{c}\text { Physical-only } \\
\text { multimorbidity } \\
n(\%, 95 \% \mathrm{Cl})\end{array}$ & $\begin{array}{c}\text { Mental-only } \\
\text { multimorbidity } \\
n(\%, 95 \% \mathrm{Cl})\end{array}$ & $\begin{array}{c}\text { Mixed physical and } \\
\text { mental multimorbidity } \\
n(\%, 95 \% \mathrm{Cl})\end{array}$ \\
\hline $25-34(n=18687)$ & $\begin{array}{c}5110 \text { (27.3) } \\
(26.7 \text { to } 28.0)\end{array}$ & $\begin{array}{c}4019(21.5) \\
(20.9 \text { to } 22.1)\end{array}$ & $\begin{array}{c}9558(51.1) \\
(50.4 \text { to } 51.9)\end{array}$ \\
\hline $35-44(n=38884)$ & $\begin{array}{l}13240(34.0) \\
\text { (33.5 to } 34.5)\end{array}$ & $\begin{array}{l}4987(12.8) \\
\text { (12.4 to } 13.2)\end{array}$ & $\begin{array}{l}20657(53.1) \\
(52.6 \text { to } 53.6)\end{array}$ \\
\hline $45-54(n=58421)$ & $\begin{array}{l}26642(45.6) \\
(45.1 \text { to } 46.0)\end{array}$ & $\begin{array}{l}3138(5.4) \\
\text { (5.1 to } 5.5)\end{array}$ & $\begin{array}{l}28641(49.0) \\
(48.6 \text { to } 49.4)\end{array}$ \\
\hline $55-64(n=85319)$ & $\begin{array}{l}49771(58.3) \\
(58.0 \text { to } 58.6)\end{array}$ & $\begin{array}{l}1626(1.9) \\
(1.8 \text { to } 2.0)\end{array}$ & $\begin{array}{l}33922 \text { (39.8) } \\
\text { (39.4 to } 40.1)\end{array}$ \\
\hline $65-74(n=91550)$ & $\begin{array}{l}62536(68.3) \\
(68.0 \text { to } 68.6)\end{array}$ & $\begin{array}{l}665(0.7) \\
(0.6 \text { to } 0.8)\end{array}$ & $\begin{array}{l}28349(31.0) \\
(30.7 \text { to } 31.3)\end{array}$ \\
\hline$\geq 75(n=103446)$ & $\begin{array}{l}65912(63.7) \\
(63.4 \text { to } 67.0)\end{array}$ & $\begin{array}{l}586(0.6) \\
(0.5 \text { to } 0.7)\end{array}$ & $\begin{array}{l}36948(35.7) \\
(35.4 \text { to } 36.0)\end{array}$ \\
\hline Total & $\begin{array}{l}223211(56.3) \\
(56.1 \text { to } 56.4)\end{array}$ & $\begin{array}{l}15021 \text { (3.8) } \\
(3.7 \text { to } 3.9)\end{array}$ & $\begin{array}{l}158075(39.9) \\
\text { (39.7 to } 40.0)\end{array}$ \\
\hline
\end{tabular}

Analysis based on 40 chronic conditions: 32 physical and eight mental. Percentages are the \% in each age group.

$8.1 \%$ of $25-34$-year-olds to $76.1 \%$ of those aged $\geq 75$ years. By the age of $\geq 55$ years, there were more people with multimorbidity than there were with a single condition or no condition.

Table 2 shows the prevalence of different types of multimorbidity (physical or mental or both) across age groups. Physical-only multimorbidity accounted for $56 \%$ of all multimorbidity overall, and was the most common type of multimorbidity from $\geq 55$ years. In contrast, the number of people with mental-only multimorbidity accounted for $<4 \%$ of multimorbidity overall, and this was most common below the age of 45 years. Mixed physical and mental multimorbidity accounted for almost $40 \%$ of all multimorbidity. It was the most common type of multimorbidity in all age groups $<55$ years, and continued to rise in prevalence after this.

\section{Effect of deprivation on type of multimorbidity}

Table 3 shows the prevalence of different types of multimorbidity (physical or mental

Table 3. Differences between types of multimorbidity by age group and deprivation

\begin{tabular}{|c|c|c|c|c|c|c|}
\hline \multirow[b]{2}{*}{ Age group, years } & \multicolumn{2}{|c|}{$\begin{array}{l}\text { Physical-only } \\
\text { multimorbidity } \\
n(\%, 95 \% \text { CI) }\end{array}$} & \multicolumn{2}{|c|}{$\begin{array}{c}\text { Mental-only } \\
\text { multimorbidity } \\
n(\%, 95 \% \mathrm{Cl})\end{array}$} & \multicolumn{2}{|c|}{$\begin{array}{l}\text { Mixed physical and } \\
\text { mental multimorbidity } \\
n(\%, 95 \% \mathrm{Cl})\end{array}$} \\
\hline & $\begin{array}{c}\text { Most } \\
\text { deprived }\end{array}$ & $\begin{array}{c}\text { Least } \\
\text { deprived }\end{array}$ & $\begin{array}{c}\text { Most } \\
\text { deprived }\end{array}$ & $\begin{array}{c}\text { Least } \\
\text { deprived }\end{array}$ & $\begin{array}{c}\text { Most } \\
\text { deprived }\end{array}$ & $\begin{array}{c}\text { Least } \\
\text { deprived }\end{array}$ \\
\hline $25-34$ & $\begin{array}{c}447(1.9) \\
(1.7 \text { to } 2.1)\end{array}$ & $\begin{array}{c}340(1.9) \\
(1.7 \text { to } 2.1)\end{array}$ & $\begin{array}{c}613(2.6) \\
(2.4 \text { to } 2.8)\end{array}$ & $\begin{array}{c}159(0.9) \\
(0.7 \text { to } 1.1)\end{array}$ & $\begin{array}{c}1289(5.4) \\
(5.1 \text { to } 5.6)\end{array}$ & $\begin{array}{c}465(2.7) \\
(2.4 \text { to } 2.9)\end{array}$ \\
\hline $35-44$ & $\begin{array}{l}1061(4.3) \\
\text { (4.1 to } 4.5)\end{array}$ & $\begin{array}{l}1040(4.1) \\
\text { (3.8 to } 4.3)\end{array}$ & $\begin{array}{c}815 \text { (3.3) } \\
\text { (3.0 to } 3.5)\end{array}$ & $\begin{array}{l}231(0.9) \\
(0.7 \text { to } 1.1)\end{array}$ & $\begin{array}{c}2844(11.5) \\
(11.1 \text { to } 11.9)\end{array}$ & $\begin{array}{l}1006 \text { (3.9) } \\
\text { (3.7 to 4.1) }\end{array}$ \\
\hline $45-54$ & $\begin{array}{l}2087(10.3) \\
(10.0 \text { to } 10.7)\end{array}$ & $\begin{array}{l}2279(8.9) \\
\text { (8.5 to } 9.2 \text { ) }\end{array}$ & $\begin{array}{c}440(2.2) \\
(2.0 \text { to } 2.4)\end{array}$ & $\begin{array}{c}184(0.7) \\
(6.2 \text { to } 8.3)\end{array}$ & $\begin{array}{c}3795 \text { (18.8) } \\
\text { (18.2 to 19.3) }\end{array}$ & $\begin{array}{l}1567(6.1) \\
(5.8 \text { to } 6.4)\end{array}$ \\
\hline $55-64$ & $\begin{array}{c}3301 \text { (22.9) } \\
\text { (22.1 to 23.8) }\end{array}$ & $\begin{array}{c}4556(20.4) \\
\text { (19.9 to 20.9) }\end{array}$ & $\begin{array}{c}147(1.0) \\
(0.8 \text { to } 1.2)\end{array}$ & $\begin{array}{c}123(0.6) \\
(4.5 \text { to } 6.5)\end{array}$ & $\begin{array}{c}3705(25.7) \\
(24.9 \text { to } 26.4)\end{array}$ & $\begin{array}{c}2156(9.7) \\
(9.2 \text { to } 10.0)\end{array}$ \\
\hline $65-74$ & $\begin{array}{c}4423 \text { (39.1) } \\
\text { (38.2 to 39.9) }\end{array}$ & $\begin{array}{c}5316(37.9) \\
\text { (37.1 to } 38.7)\end{array}$ & $\begin{array}{c}50(0.4) \\
(0.2 \text { to } 0.4)\end{array}$ & $\begin{array}{c}65(0.5) \\
(0.3 \text { to } 0.5)\end{array}$ & $\begin{array}{c}3128(27.6) \\
\text { (26.8 to } 28.4)\end{array}$ & $\begin{array}{c}1902(13.6) \\
(13.0 \text { to } 14.1)\end{array}$ \\
\hline$\geq 75$ & $\begin{array}{c}4177(46.1) \\
(45.0 \text { to } 47.1)\end{array}$ & $\begin{array}{c}6200(48.1) \\
(47.2 \text { to } 48.9)\end{array}$ & $\begin{array}{c}37(0.4) \\
(0.2 \text { to } 0.5)\end{array}$ & $\begin{array}{c}52(0.4) \\
(0.3 \text { to } 0.5)\end{array}$ & $\begin{array}{c}2887 \text { (31.8) } \\
\text { (30.8 to } 32.8 \text { ) }\end{array}$ & $\begin{array}{c}3488(27.0) \\
(26.2 \text { to } 27.8)\end{array}$ \\
\hline
\end{tabular}

Analysis based on 40 chronic conditions: 32 physical and eight mental. Percentages are the \% in each age group/deprivation group ln $=103695$ most deprived, 117708 (east deprived). 


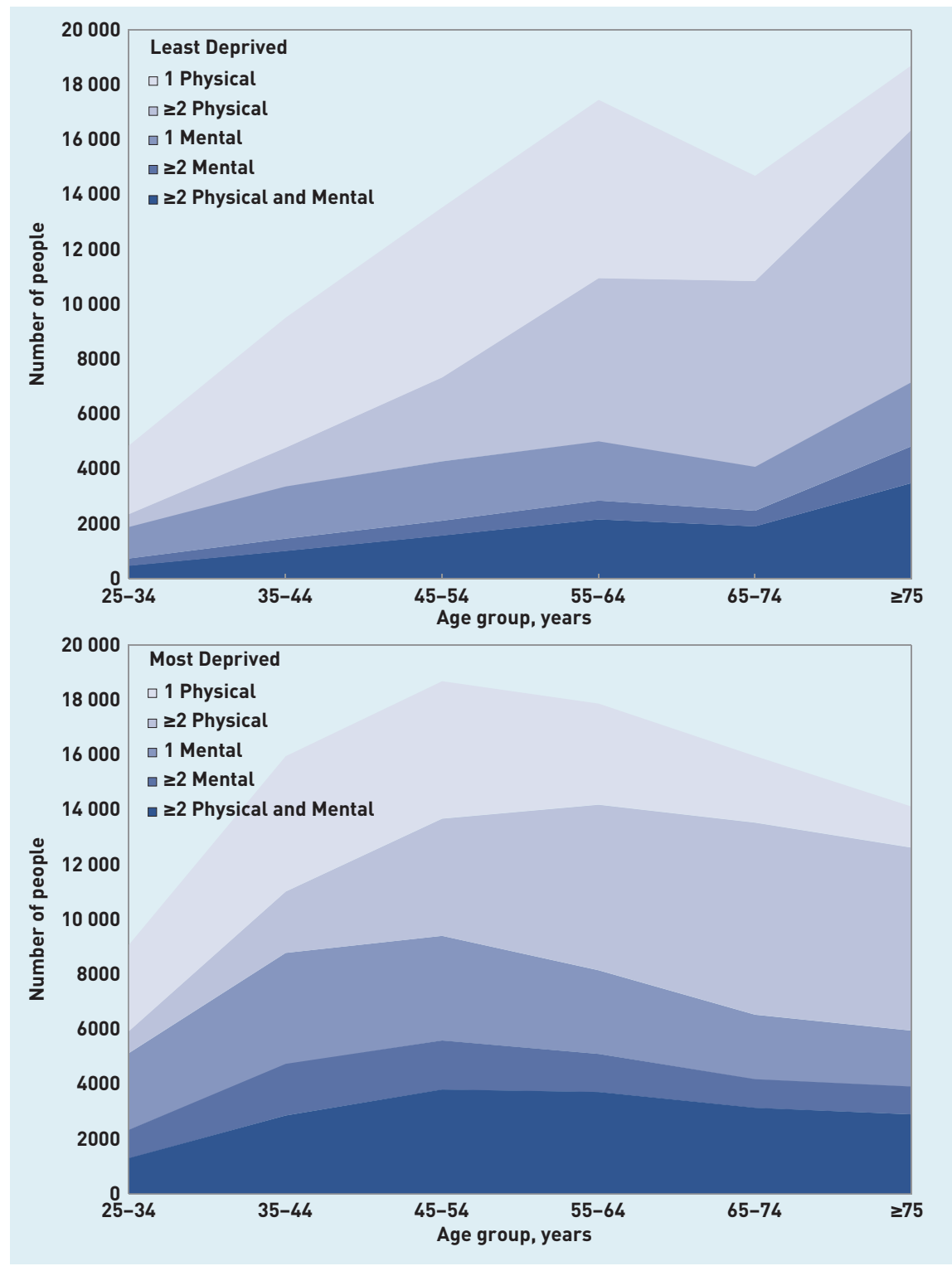

Figure 1. Number and type of chronic condition for overall population by number of patients (least and most deprived deciles). or both) across age groups for the least and most deprived deciles. Physical-only multimorbidity had a similar prevalence in the most and least deprived deciles. In contrast, the number of people with mental-only multimorbidity was markedly higher in the most deprived than in the least deprived especially in the younger age groups. The prevalence was similar in both deprivation groups $\geq 65$ years. Mixed physical and mental multimorbidity was two- to threefold more common in the most deprived compared with the least deprived in all age groups $<75$ years.

Figure 1 shows the numbers of people with the different types of multimorbidity by age group, in the most and least deprived deciles, and, for comparison, also shows the numbers with no condition or one condition (mental or physical). Although multimorbidity is more common in older people, the shape of the population distribution means that the absolute numbers of people with multimorbidity vary less by age, and there are particularly large numbers of people in the most deprived decile with mental health problems (multiple or mixed).

\section{Prevalence of individual conditions in multimorbid patients}

Table 4 shows the top 10 most prevalent conditions in multimorbid patients in each age group. Depression was the most prevalent condition for multimorbid patients in all age groups < 55 years, whereas hypertension was the most prevalent condition for those aged $\geq 55$ years. Depression and pain featured in the top five conditions across all age groups.

Ten conditions made up the top five most common conditions in multimorbid patients in each age group: seven physical conditions Ifour 'concordant' conditions with related aetiology and/or management: diabetes, $\mathrm{CHD}$, hypertension, and CKD; and three 'discordant': pain, asthma, and dyspepsia), and three mental health conditions (depression, anxiety, and drugs misuse, which includes use of prescription drugs that GPs have coded as being problematic in some wayl. The prevalence of concordant physical conditions in multimorbid patients increased with age, whereas in younger age groups multimorbidity was characterised by discordant physical conditions and mental health conditions.

\section{Effect of deprivation on the prevalence of individual conditions in multimorbid patients}

The prevalence of the ten conditions that feature in the top five conditions across age group is shown in Figure 2, by age and deprivation (most and least deprived deciles). Deprivation was associated with a higher prevalence of seven out of the 10 conditions (depression, drugs misuse, anxiety, dyspepsia, pain, CHD, and diabetes). Deprivation correlated with drug misuse and pain across all age groups; in depression and anxiety in all age groups up to those aged $\geq 75$ years; in dyspepsia in all age groups < 65 years; in CHD for those aged $\geq 45$ years; and in diabetes for those $\geq 55$ years.

\section{DISCUSSION}

\section{Summary}

Multimorbidity was characterised by age and deprivation in a large nationally 
Table 4. Age differences between the top 10 most prevalent conditions in multimorbid patients

\begin{tabular}{|c|c|c|c|c|c|c|}
\hline $\begin{array}{l}\text { Rank order } \\
\text { of conditions }\end{array}$ & $\begin{array}{c}\text { Age } 25-34 \\
\%(95 \% \mathrm{CI}) \\
n=18687\end{array}$ & $\begin{array}{c}\text { Age } 35-44 \\
\%(95 \% \mathrm{Cl}) \\
n=38884\end{array}$ & $\begin{array}{c}\text { Age } 45-54 \\
\%(95 \% \mathrm{CI}) \\
n=58421\end{array}$ & $\begin{array}{c}\text { Age } 55-64 \\
\%(95 \% \mathrm{CI}) \\
n=85319\end{array}$ & $\begin{array}{c}\text { Age } 65-74 \\
\%(95 \% \mathrm{CI}) \\
n=91550\end{array}$ & $\begin{array}{c}\text { Age } \geq 75 \\
\%(95 \% \mathrm{CI}) \\
n=103446\end{array}$ \\
\hline 1 & $\begin{array}{c}\text { Depression } \\
46.1 \text { ( } 45.3 \text { to } 46.8 \text { ) }\end{array}$ & $\begin{array}{c}\text { Depression } \\
46.9 \text { (46.4 to } 47.4)\end{array}$ & $\begin{array}{c}\text { Depression } \\
38.8 \text { (38.4 to 39.2) }\end{array}$ & $\begin{array}{c}\text { Hypertension } \\
48.5 \text { (49.2 to 48.9) }\end{array}$ & $\begin{array}{c}\text { Hypertension } \\
58.3 \text { (58.0 to } 58.6 \text { ) }\end{array}$ & $\begin{array}{c}\text { Hypertension } \\
61.9 \text { (61.5 to 62.3) }\end{array}$ \\
\hline 2 & $\begin{array}{c}\text { Drug misuse } \\
25.9 \text { (25.2 to } 26.5 \text { ) }\end{array}$ & $\begin{array}{c}\text { Pain } \\
26.4 \text { (25.9 to 26.8) }\end{array}$ & $\begin{array}{c}\text { Hypertension } \\
30.9 \text { (30.4 to 31.2) }\end{array}$ & $\begin{array}{c}\text { Pain } \\
31.3(31.0 \text { to } 31.6)\end{array}$ & $\begin{array}{c}\text { Pain } \\
30.0(29.7 \text { to } 30.3)\end{array}$ & $\begin{array}{c}\text { CHD } \\
31.2 \text { (30.9 to 31.5) }\end{array}$ \\
\hline 4 & $\begin{array}{c}\text { Anxiety } \\
19.8(19.3 \text { to } 20.4)\end{array}$ & $\begin{array}{c}\text { Anxiety } \\
17.8(17.4 \text { to } 18.1)\end{array}$ & $\begin{array}{c}\text { Dyspepsia } \\
18.4 \text { (18.1 to } 18.7)\end{array}$ & $\begin{array}{c}\text { Diabetes } \\
17.7(17.4 \text { to } 18.0)\end{array}$ & $\begin{array}{c}\text { Diabetes } \\
21.1(20.8 \text { to } 21.4)\end{array}$ & $\begin{array}{c}\text { CKD } \\
18.5(18.2 \text { to 18.7) }\end{array}$ \\
\hline 5 & $\begin{array}{c}\text { Pain } \\
19.1 \text { (18.6 to 19.7) }\end{array}$ & $\begin{array}{c}\text { Dyspepsia } \\
16.5 \text { (16.1 to } 16.8)\end{array}$ & $\begin{array}{c}\text { Asthma } \\
14.2 \text { (13.9 to } 14.4)\end{array}$ & $\begin{array}{c}\text { Dyspepsia } \\
17.2(16.9 \text { to } 17.4)\end{array}$ & $\begin{array}{c}\text { Depression } \\
18.5 \text { (18.3 to } 18.8)\end{array}$ & $\begin{array}{c}\text { Depression } \\
17.2 \text { (17.0 to } 17.4 \text { ) }\end{array}$ \\
\hline 6 & $\begin{array}{c}\text { Alcohol dependence } \\
14.5(14.0 \text { to } 15.0)\end{array}$ & $\begin{array}{c}\text { IBS } \\
15.2(14.8 \text { to } 15.5)\end{array}$ & $\begin{array}{c}\text { Diabetes } \\
13.6 \text { (13.4 to } 13.9)\end{array}$ & $\begin{array}{c}\text { CHD } \\
15.9(15.6 \text { to } 16.1)\end{array}$ & $\begin{array}{c}\text { Dyspepsia } \\
15.9(15.7 \text { to } 16.2)\end{array}$ & $\begin{array}{c}\text { Diabetes } \\
17.2 \text { (17.0 to } 17.5 \text { ) }\end{array}$ \\
\hline 7 & $\begin{array}{c}\text { IBS } \\
14.4(13.9 \text { to } 14.9)\end{array}$ & $\begin{array}{c}\text { Drug misuse } \\
14.8(14.4 \text { to } 15.1)\end{array}$ & $\begin{array}{c}\text { Anxiety } \\
13.6(13.3 \text { to } 13.9)\end{array}$ & $\begin{array}{c}\text { Thyroid } \\
13.9 \text { (13.7 to } 14.2)\end{array}$ & $\begin{array}{c}\text { COPD } \\
14.6(14.4 \text { to } 14.8)\end{array}$ & $\begin{array}{c}\text { Constipation } \\
17.0(16.7 \text { to } 17.2)\end{array}$ \\
\hline 8 & $\begin{array}{c}\text { Dyspepsia } \\
10.4 \text { (10.0 to } 10.8)\end{array}$ & $\begin{array}{c}\text { Hypertension } \\
13.7 \text { (13.3 to } 14.0 \text { ) }\end{array}$ & $\begin{array}{c}\text { IBS } \\
13.5(13.3 \text { to } 13.8)\end{array}$ & $\begin{array}{c}\text { IPA } \\
13.3(13.1 \text { to } 13.7)\end{array}$ & $\begin{array}{c}\text { Thyroid } \\
14.5 \text { (14.3 to } 14.8)\end{array}$ & $\begin{array}{c}\text { Stroke } \\
16.6(16.4 \text { to } 16.8)\end{array}$ \\
\hline 9 & $\begin{array}{c}\text { Thyroid } \\
7.5 \text { (7.1 to } 7.8 \text { ) }\end{array}$ & $\begin{array}{c}\text { Alcohol dependence } \\
13.3 \text { (13.0 to } 13.6)\end{array}$ & $\begin{array}{c}\text { Thyroid } \\
13.1 \text { (12.8 to } 13.4)\end{array}$ & $\begin{array}{c}\text { COPD } \\
11.1(10.8 \text { to } 11.3)\end{array}$ & $\begin{array}{c}\text { IPA } \\
13.7(13.5 \text { to } 13.9)\end{array}$ & $\begin{array}{c}\text { Thyroid } \\
15.9(15.7 \text { to } 16.1)\end{array}$ \\
\hline 10 & $\begin{array}{l}\text { Hearing loss } \\
6.9 \text { (6.6 to } 7.3 \text { ) }\end{array}$ & $\begin{array}{c}\text { Thyroid } \\
10.9 \text { (10.6 to } 11.2 \text { ) }\end{array}$ & $\begin{array}{c}\text { Alcohol dependence } \\
12.3(12.0 \text { to } 12.6)\end{array}$ & $\begin{array}{c}\text { Anxiety } \\
10.8(10.6 \text { to } 11.0)\end{array}$ & $\begin{array}{c}\text { Stroke } \\
10.5(10.3 \text { to } 10.7)\end{array}$ & $\begin{array}{c}\text { Hearing loss } \\
15.5 \text { (15.3 to } 15.7)\end{array}$ \\
\hline
\end{tabular}

representative sample. The prevalence of multimorbidity increased with age, with physical-only multimorbidity being the most common pattern in the over-55s, and involved many 'concordant' conditions. ${ }^{30}$ In earlier adulthood, multiple mental health conditions and mixed physical and mental conditions were more prevalent. Mixed physical and mental multimorbidity was much more common in the deprived compared with the affluent at all ages $<75$ years. Depression and pain featured in the top five conditions across all age groups, and 10 conditions (seven physical and three mental) accounted for the top five most common conditions in all age groups. Deprivation was associated with a higher prevalence of seven of these 10 conditions.

The higher prevalence of mixed mental and physical conditions that exists in the more deprived, particularly at an earlier age, may reflect previous evidence, which shows that mental health conditions are more prevalent in people with increasing physical disorders. ${ }^{30}$ It was not possible, however, to assess which condition came first for those with multimorbidity. Therefore, it may be that the higher prevalence of physical conditions such as CHD, diabetes, and pain found in the most deprived is influenced by higher rates of mental conditions occurring first, at an earlier age. Much higher rates of alcohol dependence and drugs misuse were found in the more deprived across all age groups, but particularly in those $<45$ years of age. This, along with higher rates of smoking, which are often found in the more deprived, could be a contributing factor to the development of additional physical conditions, but also other mental conditions such as depression and anxiety. ${ }^{11}$ Further work is required to assess which conditions come first and whether these differ by age and deprivation.

\section{Strengths and limitations}

There are several limitations of this study. First, as it is a secondary data analysis the study is reliant on the quality of primary data recording. Some of the conditions included in this study are likely to be underrecorded, implying that any findings will underestimate the true prevalence of multimorbidity. Second, multimorbidity is defined using a simple count of conditions, which does not take account of the 

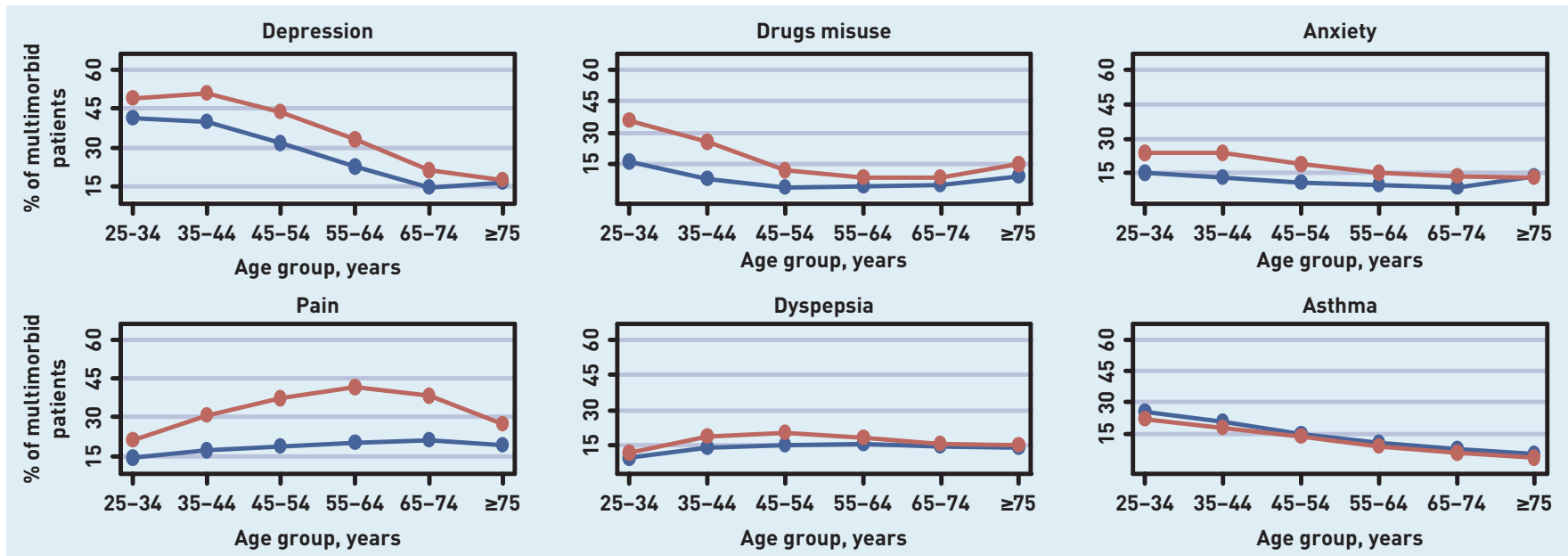

Dyspepsia
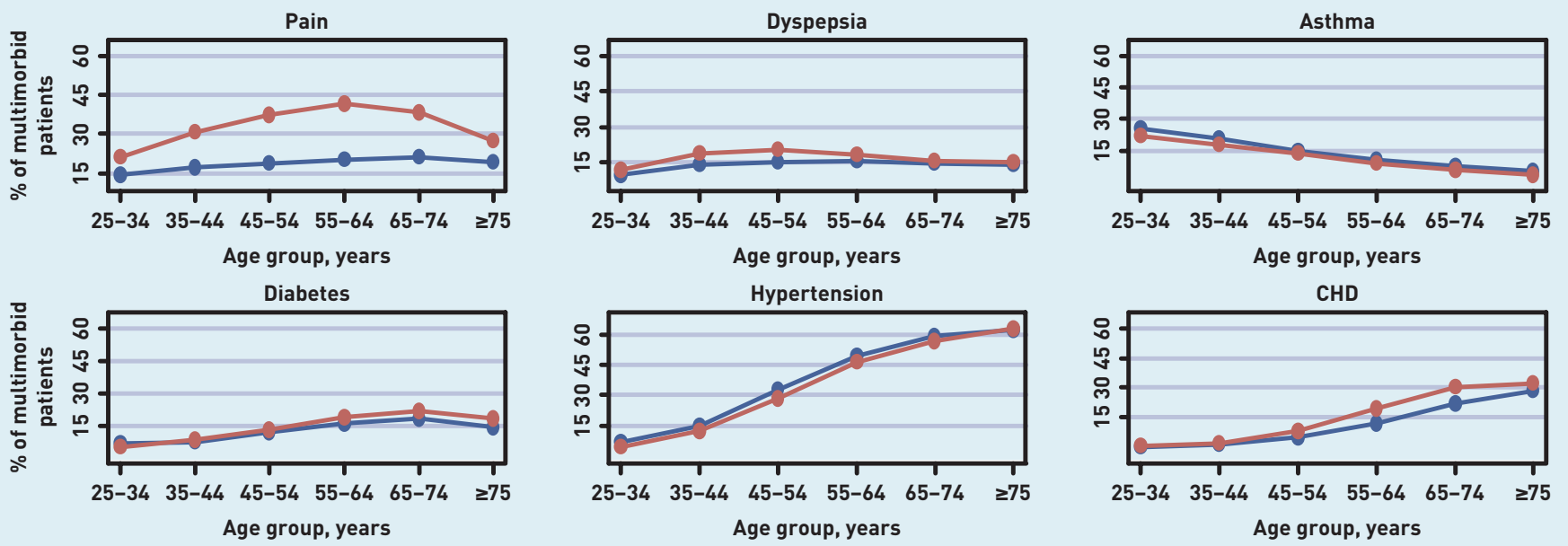

Hypertension
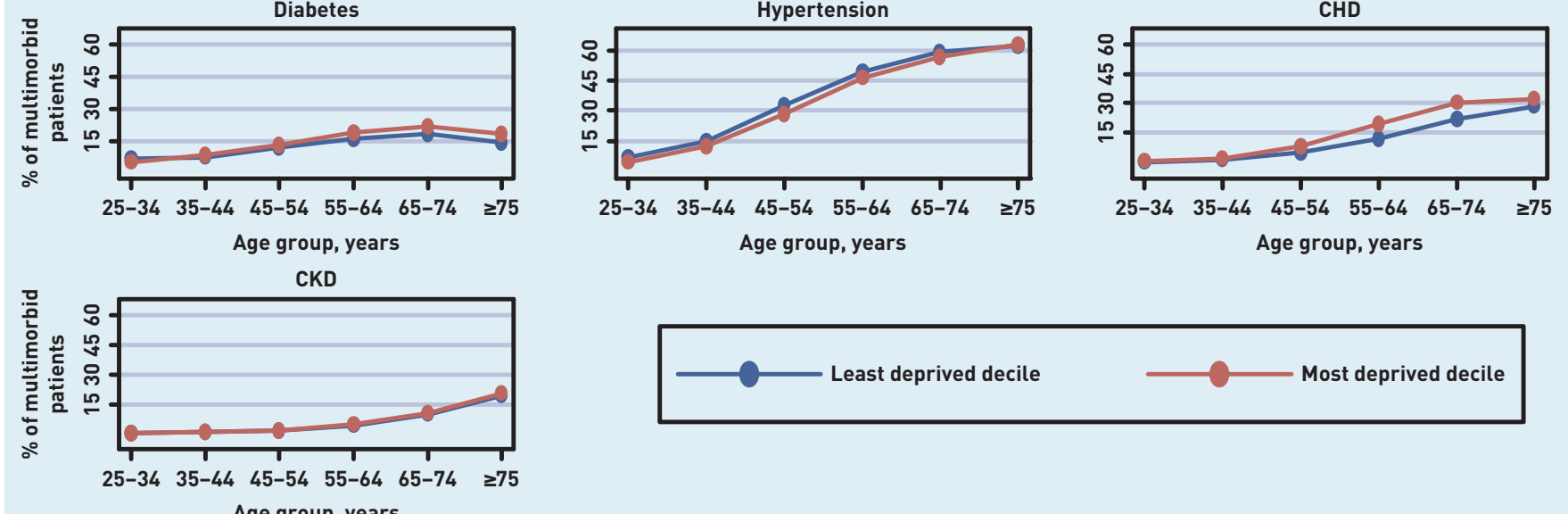

Figure 2. Prevalence of most common conditions in multimorbid patients, by age and deprivation. $C K D=$ chronic kidney disease. $C H D=$ coronary heart disease

varying effect on individuals of different combinations of conditions or their severity. Third, the way that different 'conditions' are defined in the database may lead to some problems. For instance, the relatively high prevalence of hearing loss in the youngest age group may be explained by its definition as 'ever recorded'. This could, therefore, include glue ear at a younger age. The trade-off in this case is that if hearing loss had been defined as 'recorded in the last 5 years', it would be liable to undercount persistent deafness in older people, which is already likely to be underrecorded. Similarly, using prescribing as part of the definition of certain conditions (such as anxiety) has the potential both to underestimate lfor example, in the case of anxiety that is managed nonpharmacologicallyl and overestimate (for example, when anxiolytics are used for other conditions) the true prevalence of those conditions. Such problems are common to all similar database studies and this study's approach has been to be pragmatic and transparent, with full condition definitions published. ${ }^{15}$
A strength of the study is its large size and the representativeness of the Scottish nation. It includes 40 conditions, which is substantially more than most similar studies. ${ }^{12}$ It also covers all age groups and is representative of the whole population in terms of age, sex, and socioeconomic status, making the findings more broadly applicable to other settings than most similar studies. ${ }^{21,23,32,33}$

\section{Comparison with existing literature}

It is believed that this is the largest study to examine multimorbidity by age and deprivation using a wide range of conditions. A study in Canada of the presence of 16 conditions in 5010 adults aged $>18$ years found that age, sex, income, and family structure were independently associated with multimorbidity. ${ }^{20}$ Much of the focus of multimorbidity research has been on older age groups, however, with little assessment of the impact of socioeconomic deprivation. ${ }^{34}$ Results from this study are in line with previous findings showing that although multimorbidity increases with age, the absolute numbers 
of people with multimorbidity are more evenly spread across ages than generally assumed, particularly in socioeconomically deprived populations. ${ }^{23,31,32,35}$ Studies that have examined multimorbidity across age groups have generally focused on overall multimorbidity count rather than on the prevalence of individual conditions in the multimorbid. ${ }^{15,21}$ An Australian study of 1651 patients with multimorbidity lusing a smaller number of conditions than in the present studyl found that adults $<40$ years of age most commonly had a mental health condition lanxiety, depression, stress-related problem, other mental health problem) and asthma as a cluster, whereas in those aged 40-59 years the most common cluster was a mental health condition and arthritis.

Higher rates of multimorbidity and particularly mental health conditions in more deprived areas have been found elsewhere..$^{34,36-37}$ The higher prevalence of depression and pain in more deprived areas found in this analysis contrasts with results from a German study of 3189 multimorbid people aged $\geq 65$ years, which found an association between higher rates of multimorbidity (based on 46 chronic conditions) and deprivation, but no association in the older people studied between deprivation and the presence of one or more conditions in a study defined cluster of 'anxiety, depression, somatoform disorders, and pain'.38 A cross-sectional analysis of 7305 participants aged $\geq 50$ years in the US investigated the association between childhood financial hardship, lifetime earnings, and multimorbidity. ${ }^{39}$ The study found that childhood financial hardship and lifetime earnings are associated with multimorbidity, but not associated with the absence of morbidity. ${ }^{38}$

\section{Open access}

This article is Open Access: CC BY-NC 3.0 license (http://creativecommons.org/ licenses/by-nc/3.0/).

\section{Acknowledgements}

We thank Primary Care Clinical Informatics Unit at the University of Aberdeen, which provided the data contained herein. The views in this publication are not necessarily the views of the University of Aberdeen, its agents, or employees. We thank Katie Wilde and Fiona Chaloner of the University of Aberdeen, who did the initial data extraction and management. Sally Wyke is also interdisciplinary research professor at Florentine House, Glasgow, UK.

\section{Discuss this article}

Contribute and read comments about this article: www.bjgp.org.uk/letters holistic and integrated primary care services led by generalists, which if not met - because of the persistence of the inverse care law - is likely to widen inequalities in health. ${ }^{42-44}$ This threat is potentially greatest for the under $65 \mathrm{~s}$ with multimorbidity, as geriatricians often work in a way that complements and supports generalist GPs, whereas in many countries there are fewer, if any, secondary care generalist physicians for younger adults. Existing approaches to medical education, research, and healthcare delivery focus on single diseases, but a growing body of research has called for a redesign in health systems to meet the challenges of increasing multimorbidity. ${ }^{15}$ Evidence has shown that physical multimorbidity is strongly associated with unplanned admission to hospital, including admissions that were potentially preventable. ${ }^{39}$ Furthermore, the risk of admission to hospital was exacerbated by the coexistence of mental health conditions and socioeconomic deprivation and was also higher in the youngest age groups compared with the middle-aged. It has also been shown that for those with mental health problems there is a marked social patterning for hospital admissions. ${ }^{45}$ Given the higher rates of combined physical and mental multimorbidity in the younger age groups, particularly in the most deprived areas, this suggests that focusing on these people could offer potential for a reduction in preventable admissions. The evidence base for the effect of multimorbidity on mortality and hospital admissions remains small, however, and further work is required in this area.

Results from this study add weight to this call but also suggest the need for interventions, particularly in the most deprived areas, aimed at the younger adults and the large numbers of patients with coexisting physical and mental multimorbidity.

Mixed physical and mental multimorbidity is common across the life-span and is exacerbated by deprivation from early adulthood onwards. Individuals in more deprived areas face the challenge of multimorbidity in greater numbers characterised by mixed mental and physical conditions from an earlier age and lasting longer over the life-course. The findings of this study highlight the need for longitudinal studies that can take a life-course approach to aetiological understandings of the determinants of different patterns of multimorbidity and how they interact over the life-span. 


\section{REFERENCES}

1. Fortin M, Bravo G, Hudon C, et al. Prevalence of multimorbidity among adults seen in family practice. Ann Fam Med 2005; 3: 223-228.

2. Fortin M, Soubhi H, Hudon $\mathrm{C}$, et al. Multimorbidity's many challenges. BMJ 2007; 334: 1016-1017.

3. Stange KC. The generalist approach. Ann Fam Med 2009; 7: 198-203.

4. Boyd CM, Darer J, Boult C, et al. Clinical practice guidelines and quality of care for older patients with multiple comorbid diseases. JAMA 2005; 294: 716-724.

5. Tooth L, Hockey R, Byles J, Dobson A. Weighted multimorbidity indexes predicted mortality, health service use, and health-related quality of life in older women. J Clin Epidemiol 2008; 61: 151-159.

6. Lee TA, Shields AE, Vogeli C, et al. Mortality rate in veterans with multiple chronic conditions. J Gen Intern Med 2007; 22 Suppl 3: 403-407.

7. Fortin M, Bravo G, Hudon C, et al. Relationship between multimorbidity and health-related quality of life of patients in primary care. Qual Life Res 2006; 15: 83-91

8. Bayliss EA, Ellis JL, Steiner JF. Barriers to self-management and quality-of-life outcomes in seniors with multimorbidities. Ann Fam Med 2007; 5: 395-402.

9. Gijsen R, Hoeymans N, Schellevis FG, et al. Causes and consequences of co morbidity: A review. J Clin Epidemiol 2001; 54: 661-674.

10. Schoenberg NE, Kim H, Edwards W, Fleming ST. Burden of common multiplemorbidity constellations on out-of-pocket medical expenditures among older adults. Gerontologist 2007; 47: 423-437.

11. France EF, Wyke S, Gunn JM, et al. Multimorbidity in primary care: a systematic review of prospective cohort studies. Br J Gen Pract 2012; DOI: 10.3399/ bjgp12X636146.

12. Diederichs $C$, Berger $\mathrm{K}$, Bartels DB. The measurement of multiple chronic diseases-a systematic review on existing multimorbidity indices. J Gerontol Series A-Biolog Sci Med Sci 2011; 66(3): 301-311.

13. Lyness J, Niculescu A, Tu Xin, Reynolds CF, Caine ED. The relationship of medical comorbidity and depression in older, primary care patients. Psychosomatics 2006; 47: 435-439.

14. Salisbury C, Johnson L, Purdy S, et al. Epidemiology and impact of multimorbidity in primary care: a retrospective cohort study. Br J Gen Pract 2011; DOI: 10.3399/bjgp11X548929

15. Barnett K, Mercer SW, Norbury M, et al. The epidemiology of multimorbidity in a large cross-sectional dataset: implications for health care, research and medical education. Lancet 2012; 380(9836): 37-43.

16. Schäfer I, von Leitner EC, Schön G, et al. Multimorbidity patterns in the elderly: a new approach of disease clustering identifies complex interrelations between chronic conditions. PLOS ONE2010; 5: e15941.

17. van den Bussche $\mathrm{H}$, Koller D, Kolonko $\mathrm{T}$, et al. Which chronic diseases and disease combinations are specific to multimorbidity in the elderly? Results of a claims data based cross-sectional study in Germany. BMC Public Health 2011; 11: 101

18. Marengoni A, Rizzuto D, Wang HX, et al. Patterns of chronic multimorbidity in the elderly population. J Am Geriatr Soc 2009; 57(2): 225-230.

19. Akner $G$. Analysis of multimorbidity in individual elderly nursing home residents. Development of a multimorbidity matrix. Arch Gerontol Geriatr 2009; 49(3): 413-419.

20. Agborsangaya CB, Lau D, Lahtinen M, et al. Multimorbidity prevalence and patterns across socioeconomic determinants: a cross-sectional survey. BMC Public Health 2012; 12: 201

21. Taylor AW, Price K, Gill TK, et al. Multimorbidity - not just an older person's issue. Results from an Australian biomedical study. BMC Public Health 2010 10: 718

22. Mercer SW, Watt GCM. The inverse care law: clinical primary care encounters in deprived and affluent areas of Scotland. Ann Fam Med 2007; 5(6): 503-10.

23. Ben-Shlomo Y, Kuh D. A life course approach to chronic disease epidemiology: conceptual models, empirical challenges and interdisciplinary perspectives. Int J Epidemiol 2002; 31: 285-293.

24. Colman I, Ataullahjan A. Life course perspectives on the epidemiology of depression. Can J Psychiatry 2010; 55(10): 622-632

25. Elder R, Kirkpatrick M, Ramsay W, et al. Measuring quality in primary medical services using data from SPICE. Edinburgh, Scotland: NHS National Services Scotland, 2007.

26. Carstairs V, Morris R. Deprivation and health in Scotland. Aberdeen: Aberdeen University Press, 1991.

27. McLoone P. Carstairs scores for Scottish postcode sectors from the 2001 Census. 2004. MRC Social \& Public Sciences Unit, University of Glasgow. http://mww.sphsu.mrc.ac.uk/library/other\%20reports/Carstairs_report.pdf (accessed 8 May 2014).

28. NHS-Primary Care Commissioning. QOF Business rules v24.0. http://www.pcccic.org.uk/article/qof-business-rules-v240 (accessed 3 Jun 2014).

29. Piette JD, Kerr EA. The impact of comorbid chronic conditions on diabetes care. Diabetes Care 2006; 29(3): 725-731

30. Gunn J, Ayton D, Densley K, et al. The association between chronic illness, multimorbidity and depressive symptoms in an Australian primary care cohort. Soc Psychiat Epidemiol 2012; 47: 175

31. Shohaimi S, Luben R, Wareham N, et al. Residential area deprivation predicts smoking habit independent of individual educational level and occupational social class. A cross sectional study in the Norfolk cohort of the European Investigation into Cancer (EPIC-Norfolk). J Epidemiol Commun H2003; 57: 270-276.

32. van den Akker M, Buntinx F, Metsemakers JF, et al. Multimorbidity in general practice: prevalence, incidence, and determinants of co-occurring chronic and recurrent diseases. J Clin Epidemiol 1998; 51(5): 367-375.

33. Jani B, Bikker AP, Higgins M, et al. Patient centeredness and the outcome of primary care consultations with patients with depression in areas of high and low socioeconomic deprivation. Br J Gen Pract 2012; 10.3399/bjgp12X653633.

34. Smith SM, Soubhi H, Fortin M, et al. Managing patients with multimorbidity: systematic review of interventions in primary care and community settings. BMJ 2012; 345: e5205

35. van Oostrom SH, Picavet HS, van Gelder BM, et al. Multimorbidity and comorbidity in the Dutch population - data from general practices. BMC Public Health 2012; 12: 715 .

36. Marengoni A, Angleman S, Melisa R, et al. Aging with multimorbidity: a systematic review of the literature. Ageing Res Rev 2011; 10: 430-439.

37. Glynn LG, Valderas JM, Healy P, et al. The prevalence of multimorbidity in primary care and its effect on health care utilization and cost. Fam Pract 2011; 28(5): 516-523.

38. Schäfer I, Hansen H, Schön $G$, et al. The influence of age, gender and socioeconomic status on multimorbidity patterns in primary care. First results from the MultiCare Cohort Study. BMC Health Serv 2012; Res 12: 89

39. Tucker-Seeley RD, Li Y, Sorensen G, Subramanian SV. Lifecourse socioeconomic circumstances and multimorbidity among older adults. BMC Publ Health 2011; 12: 313. doi: 10.1186/1471-2458-11-313

40. Payne RA, Abel GA, Guthrie B, Mercer SW. The effect of physical multimorbidity, mental health conditions and socioeconomic deprivation on unplanned admissions to hospital: a retrospective cohort study. CMAJ 2013; 185(5): E221-E228.

41. Smith DJ, Langan J, McLean G, et al. Schizophrenia is associated with excess multiple physical comorbidities but low levels of cardiovascular disease in primary care: cross-sectional study. BMJ Open 2013; 3(4).

42. Watt $G$. The inverse care law today. Lancet 2002; 360(9328): 252-254.

43. Mercer SW, Gunn J, Bower P, et al. Managing patients with mental and physical multimorbidity. BMJ 2012; 345: e5559.

44. Guthrie B, Payne, $K$, Alderson $P$, et al. 'Adapting clinical guidelines to take account of multimorbidity.' BMJ 2012; 345: e6341

45. McCartney G, Hart C, Watt G. How can socioeconomic inequalities in hospital admissions be explained? A cohort study. BMJ Open 2013; 3(8) 